\title{
PALAVRA DO CORPO: CONFLUÊNCIA DE LINGUAGENS EM NIGHT JOURNEY
}

Aguinaldo Moreira de SOUZA ${ }^{1}$

- RESUMO: Trata-se de um exercício de leitura da coreografia Night Journey (1947), de Martha Graham, como reinvenção do texto de Édipo rei (século IV a. C.), de Sófocles. Pretende-se esboçar um estudo em que se evidenciem os processos interartísticos entre literatura e dança.

- PALAVRAS-CHAVE: Literatura; dança; corpo; linguagem; semiótica.

O presente exercício focaliza especificamente a questão do discurso interartístico, como fenômeno contemporâneo que se torna fonte de diversas produções no campo das artes, oferecendo vastas possibilidades de abordagem do ponto de vista crítico e estético, tal como o apresenta Claus Clüver (2001, p.1-42). O discurso interartístico revitaliza os gêneros artísticos, reinventa as formas, age de modo a constituir uma plurilinguagem. Incorpora elementos constitutivos de várias formas artísticas ou de outras áreas do conhecimento e da realidade (elementos não-artísticos). Uma vez incorporado, o elemento textual, em qualquer que seja o registro, estará deslocado de seu contexto original, funcionando como pólo gerativo de sentidos novos, em novas relações estruturais e sintáticas, o que caracteriza, grosso modo, o fazer artístico.

Com a ascendência da semiótica (Peirce, 1977), tem se tornado comum o estudo de trabalhos artísticos como complexas estruturas de sig-

1 Doutorando em Letras - Faculdade de Ciências e Letras - UNESP - 19800-230 - Assis - SP. 
nos, bem como a possibilidade de se chamar a esses objetos artísticos de "textos". Dessa forma, uma coreografia, um soneto, uma ópera, uma catedral e um filme fazem parte de um universo textual a ser "lido". A partir dessa concepção de texto em sentido amplo, ressalta a semiótica que se pode oferecer a terminologia necessária para esse processo de leitura. No panorama artístico contemporâneo, a contaminação das formas artísticas, a intertextualidade, o dialogismo, a interdisciplinaridade e a intersemiotização dos códigos representam procedimentos artísticos que o leitor poderá detectar. Tais procedimentos definem a abordagem crítica do fenômeno literário por meio de seus processos dinâmicos de produção e recepção (Perrone-Moisés, 1990). Apresentando-se como metalinguagens específicas, mesmo que teoricamente destinadas primeiramente ao discurso literário, as teorias de análise do texto podem ser aplicadas a outros fenômenos interartísticos.

Pretende-se, neste trabalho, esboçar um estudo em que se evidenciem os processos interartísticos entre literatura e dança. Trata-se do aparecimento de uma nova possibilidade discursiva, que se fecunda na relação que pode ser estabelecida entre essas duas formas artísticas. O que se torna um ato complexo, principalmente pelo casamento entre produções textuais verbais e produções não-verbais, distintas de outras registradas pelo pincel ou pela câmera. Assume-se como ponto de partida a ocorrência, na atualidade, de inúmeros espetáculos cênicos que tratam de constituir uma relação intersemiótica dessas duas formas artísticas. Para tanto, há que se notar a existência, na história da cultura, de momentos de aproximação entre a palavra e o gesto, entre a linguagem e o movimento, momentos em que a literatura registrou a dança e momentos em que a dança incluiu a literatura.

Por outro lado, a sintonia de estruturas e de ideologias entre discursos distintos pode também ser averiguada como possibilidade comparatista. Composições coreográficas podem se comportar estruturalmente como narrativa ou poesia, bem como estruturar sua "diegese" de modo a estabelecer relações sintagmáticas ou paradigmáticas análogas a procedimentos literários. Tais manifestações constituem amostragens e funcionam como ponto de apoio para o início de uma reflexão acerca da relação entre essas duas linguagens. Nesse ponto, ressalta a questão metodológica de como abordar os fenômenos artísticos tomados como objeto de análise. Primeiramente há que se considerar o fato de haver versões históricas que demonstram uma periodização da literatura e da dança, numa atitude classificatória, construindo um cânone que, em opinião mais recente, precisa ser redimensionado. 
Como sugere Haroldo de Campos (1969), há duas maneiras de se abordar o fenômeno literário, que aqui é assumido como maneiras de abordar outros tipos de manifestações artísticas, num procedimento analítico. Segundo o crítico em questão, no critério histórico, ressalta o estudo diacrônico, que aponta para as características do fenômeno (literário) ao longo de um determinado período. Por outro lado, o critério estético-criativo pautar-se-ia por um estudo sincrônico, que seria crítico e retificador sobre as coisas julgadas no critério histórico. Assim, a poética diacrônica tem importância apenas para uma demarcação de terreno, uma vez que traz à tona uma "média" evolutiva da tradição. A descrição sincrônica é uma maneira de privilegiar o ponto de vista estrutural. Cabe ressaltar que, de acordo com o autor de Por uma poética sincrônica, diacronia e sincronia estão em relação dialética. As tradições estão imersas no diacrônico; e sincrônica é a postura que se assume perante o diacrônico, aceitando ou recusando a tradição transmitida.

Portanto, no conjunto de referências que se podem encontrar, a respeito da relação entre a literatura e a dança, na historiografia tradicional, há que se fazer um corte sincrônico, visando a um aprofundamento naquele ponto específico selecionado. A partir daí, poder-se-á traçar um diálogo crítico entre a referência histórica e o critério estético. Nesse ínterim, será observada a gênese de um discurso produzido e recebido como interartístico.

Para este esboço de análise, a estética peirciana será adotada como modelo sistemático de investigação. A semiótica, no dizer de Lúcia Santaella (1983), é a ciência que tem por objetivo de investigação todas as linguagens; o exame dos modos de constituição de todo e qualquer fenômeno como fenômeno de produção de significação e sentido. Sendo assim, a teoria de Charles Sanders Peirce serve de ponto de partida para inúmeros trabalhos voltados para a questão das linguagens. Do mesmo modo, tal teoria pode ser adotada para a análise de um texto não-verbal específico: a coreografia em Dança moderna de Martha Graham, intitulada Night Journey (1961). No entanto, cabe perceber que alguns ajustes se fazem necessários aos modelos peircianos para uma análise mais procedente. E é nesse sentido que apontam-se aqui alguns pressupostos teóricos que, por assim dizer, utilizam as categorias semióticas e voltam-se para a questão da comunicação não-verbal. Nesse ponto, propõem novas categorias e ajustam nomenclaturas. Com relação à comunicação (não-verbal) corporal tem-se a Teoria Cinésica de Birdwistell (apud Littlejohn, 1982), a Teoria Proxêmica de Hall (apud Littlejohn, 1982) e a Teoria Funcional de Paul Ekman e Wallace Friesen. 
Essas teorias, ao que parece, podem sugerir uma abertura de perspectivas para a leitura do texto não-verbal. Como referencial prático, pode-se abordar a aplicação da teoria semiótica a textos não-verbais. Nesse sentido, observam-se os procedimentos da análise de Julio Plaza sobre a pintura Guernica, de Pablo Picasso, e o texto de Lucrécia D'Alessio Ferrara, chamado A leitura sem palavras (1986), em que a autora procede a uma leitura do espaço urbano, a partir dos apontamentos de Peirce. Com vistas a uma leitura da relação interartística protagonizada pelos discursos coreográfico e literário, pressupõe-se o reconhecimento da tragédia grega Édipo rei, de Sófocles, bem como os diversos mitos que, a partir desse texto literário-teatral, engendram-se na cultura ocidental. Além disso, o distanciamento temporal (diacronia) e as tendências modernas de releitura da tradição (bem como a constatação da instituição, na modernidade, de uma arte plural, compósita e ambígua) devem ser levados em conta.

São tópicos para este trabalho: a comunicação não-verbal; a comparação entre o texto verbal e o texto não-verbal; a analogia estrutural entre o texto verbal e o não-verbal artísticos; a dança como texto nãoverbal; as noções de interdisciplinaridade e a intertextualidade; a intersemiotização como abordagem possível do texto plural, aqui compreendidos como espetáculos que utilizam várias linguagens em seu processo de composição artística.

\section{A comunicação não-verbal}

A questão da comunicação não-verbal torna-se um pressuposto teórico para o exercício de leitura que aqui se pretende. Para a professora Lucrécia Ferrara, todo código é constituído por signos que criam a sua própria sintaxe. Ler um código (decodificar) é identificar esses signos e sua sintaxe, é justamente esse ponto que o professor Aguinaldo Gonçalves (1989) vai ressaltar como estratégico para a detecção das homologias estruturais. Nesse sentido, qualquer obra artística apresenta um processo de composição que passa por etapas e estabelece estruturas internas (e externas na medida em que se relacionam com a história da cultura como um todo). Estruturas essas que podem ser investigadas em teor metalingüístico, espaço em que se podem detectar coincidências de procedimentos formais, conceitos e estéticas. No entanto, de volta ao texto de professora Lucrécia Ferrara, quando se trata de um texto não-verbal, não há um 
código estruturado. O signo não-verbal apresenta baixa definição, uma informação pouco saturada quanto à precisão de seus dados. $\mathrm{O}$ que não impede essa informação de ser rica, somente que se torna uma árdua e diversificada tarefa para o receptor.

Essa dificuldade de leitura decorre da fragmentação da estrutura sígnica da informação. Num texto não-verbal não se encontra um signo, mas signos aglomerados sem convenções: sons, palavras, cores, traços, tamanhos, texturas, cheiros. Assim, as emanações dos cinco sentidos surgem juntas e simultâneas, porém desintegradas; uma vez que não há convenção, não há uma sintaxe que relacione ordenadamente essas emanações. A princípio, o texto não-verbal tem seu reconhecimento comprometido porque nele inexiste o significado, que é o elemento básico de todo ato de linguagem. O sentido do texto não-verbal decorre da sua própria estrutura significante, do próprio modo de produzir-se no e entre os resíduos sígnicos que o compõem. Esse significado, na verdade, não está dado, mas pode produzir-se. O texto não-verbal, por fim, tem uma outra lógica, em que o significado não se impõe, mas pode se distinguir sem hierarquia, numa simultaneidade. Segundo Lucrécia Ferrara, a essa fragmentação dos códigos, variedade e combinação de vários signos dá-se o nome de intersemiotização: linguagem complexa estruturalmente, porém mais eficiente como possibilidade de representação.

\section{Comparação entre o texto verbal e o texto não-verbal; a analogia entre o verbal e o não-verbal artísticos}

Pensando-se na gama de procedimentos de composição textual (e, por conseguinte, intertextual), há uma gradação entre o nível informacional de cada tipo de texto, que está relacionado com a dificuldade de leitura, e a possibilidade de interpretações virtuais (ou seja, níveis de percepção semióticos, centrados no interpretante dinâmico). Nesse sentido, pode-se pensar numa tabela que envolva quatro estágios:

a) o texto verbal referencial: apresenta um alto nível de definição informacional, exigindo do interpretante o domínio do código lingüístico em questão e referências contextuais.

b) o texto não-verbal referencial: (descrito por Ferrara) é uma experiência cotidiana e sem emissor evidente, não apresenta precisão dos dados informacionais, exigindo do receptor uma ação interpretante, baseada em associações. 
c) o texto verbal artístico: (literatura, também comentado, de certo modo por Ferrara) possui uma operação sistemática sobre o signo lingüístico, buscando a fuga da referencialidade e alcance da plurissignificação. $\mathrm{O}$ receptor não tem fácil acesso às informações, dependendo do esforço intelectual para a construção de uma possibilidade interpretativa dentro das virtualidades do texto. Há, portanto, uma alta definição quanto ao signo/objeto, porém a ação artística reelabora e pluraliza as informações.

d) o texto não-verbal artístico: (incluindo-se nesse sentido as artes plástico-visuais e as artes cênicas, hipótese deste trabalho) essa modalidade textual possui a característica da baixa definição informacional do texto não-verbal, potencializada pela plurissignificação do texto artístico. Nesse sentido, há a conjugação de elementos colhidos na experiência cotidiana não-verbal, que pressupõe associações de similaridade, com a elaboração formal e conteudística da obra artístico-literária, quanto à dificuldade de acesso às informações, exigindo esforço intelectual para a construção de uma possibilidade interpretativa dentro das virtualidades que se apresentam ao leitor/espectador.

Há, portanto, uma variedade de gêneros e modalidades artísticas que podem ser assim descritas, desde a pintura até o espetáculo de dança, passando pela música instrumental, escultura, gravura, instalações, performances etc.

\section{A dança como texto não-verbal artístico}

Artes como a pintura, a escultura e a arquitetura constituem textos não-verbais, possibilidades comunicativas elaboradas artisticamente, bem como os cenários de uma peça teatral ou mesmo as locações (internas e externas) de um filme. Pensando-se na questão das possibilidades de manifestações artísticas que incorporam elementos verbais e nãoverbais, ressaltam o teatro e a dança como artes que necessitam da presença do corpo do homem. Estes não são artes figurativas como as já citadas, mas sim interpretativas em sua especificidade.

A dança distancia-se por fim do teatro por fazer constituir uma linguagem não-verbal diretamente ligada ao corpo. Assim, a dança faz uso de um elemento de comunicação não-verbal atuante no mundo que é o corpo. O corpo humano desfila pelo mundo construindo infinitos textos aos olhos dos próprios homens o tempo todo, que são espectadores desse 
tipo de texto durante toda a vida. E não se pode negar que praticamente todas as formas de arte consideram a expressão do corpo, confirmando o caráter antropocêntrico indiscutível da natureza humana, que vislumbra (ou persegue) a própria figura mesmo em representações mais abstratas (não-figurativas). Contudo, o corpo humano pode ser também o instrumento para a reelaboração dessas mensagens para a construção de outras mensagens inusitadas, a partir do tratamento artístico, ou seja, pela dança. No dizer de Helena Katz, a dança é o pensamento do corpo e é ela que impede o movimento humano de morrer de clichê.

Nesse sentido, toda representação artística torna-se uma imagem do mundo recomposta a partir de um dado sistema de signos. A dança busca com seus instrumentos maiores: o gesto e o movimento do corpo, recodificar o real, potencializando-o como iconicidade e mesmo simbolismo. Cabe ressaltar que estaria aí um processo que, em princípio, une todas as formas artísticas. O objeto que se faz presente e exigente é a própria vida do homem. Essa vida, como objeto do signo, apresenta-se como recorte, apenas uma face, que se sujeitará à ação interpretante. O gesto cotidiano (clichê, do trabalho, da comunicação interpessoal) pode ser fragmentado, reelaborado e estilizado pela dança. Esta o potencializa com a expressividade artística, fornecendo a princípio uma espécie de reconhecimento, para depois transformá-lo em mistério perante os olhos do espectador.

A dança age, portanto, sobre o gesto convencional, transformando-o num índice ou ícone, descaracterizando-o para possibilitar uma expressão mais ampla, aberta, plurissignificativa. Nesse sentido, como forma de arte que é, a dança opera uma transgressão à segurança informacional. Ela faz uma representação parcial do universo que chega ao receptor pelos sentidos, mas não busca a fidelidade a esses sentidos, não possui uma relação segura com o objeto que representa. A ação interpretante será complexa e, dependendo do repertório e do esforço intelectual do receptor, ele poderá passar pelos três níveis de análise e/ou leitura propostos por Peirce: primeiridade, secundidade, terceiridade.

Diante de tais considerações, passa-se a apresentar algumas teorias que tratam da comunicação corporal, no intuito de conquistar um vocabulário adequado à referência corporal da arte da dança, facilitando os contrapontos que se pretende estabelecer entre as estruturas literárias e as estruturas coreográficas. A teoria cinésica, de Ray Birdwhistell (apud Litllejohn, 1982), considera a comunicação um fenômeno de multicanais, propondo um estudo dos gestos em contexto, comparando o sistema cinésico com o sistema lingüístico. Associa os comportamentos corporais com significados elementares que podem se combinar em unidades 
mais complexas e em trechos extensos de comportamento estruturado. A teoria cinésica compreende três níveis (que aqui se podem tomar como correspondentes ou análogos às categorias semióticas): a) precinésicaestudo fisiológico da atividade corporal - estrutura (sem busca de significado); b) microcinésica - estudo de unidades comportamentais de análise (significados isolados); c) cinésia social - estudo do comportamento em contexto e o estabelecimento de seu significado de comunicação.

Num nível corporal, têm-se os cines (movimentos funcionais), os cinemas (grupos de cines intercambiáveis em contexto); a cinemorfe (combinação complexa de cinemas em todo o corpo). De acordo com Stephen W. Littlejohn, essa teoria apresenta como pressupostos: a) tal como outros eventos da natureza, nenhum movimento ou expressão corporal é destituído de significado no contexto em que se apresenta; b) tal como outros aspectos do comportamento humano, a postura corporal, o movimento e a expressão facial são padronizados e, por conseguinte, estão sujeitos à análise sistemática; c) embora sejam reconhecidas as possíveis limitações impostas por substratos biológicos particulares, até que seja demonstrado o contrário, o movimento corporal sistemático dos membros de uma comunidade é considerado uma função do sistema social a que o grupo pertence; d) a atividade corporal visível, tal como a atividade acústica audível, influencia sistematicamente o comportamento de outros membros de qualquer grupo; e) até que se demonstre o contrário, tal comportamento será considerado uma função comunicativa investigável; f) os significados daí derivados são funções tanto do comportamento como das operações pelas quais é investigado; g) o sistema biológico particular e a experiência especial de vida de qualquer indivíduo contribuirão como elementos idiossincráticos para o seu sistema cinésico, mas a qualidade individual ou sintomática desses elementos só pode ser avaliada após a análise do sistema mais vasto de que eles são parte integrante.

Por outro lado, a Teoria Proxêmica de Edward Hall (apud Littlejohn, 1982) diz que, assim como a linguagem varia de cultura para cultura, o mesmo ocorre com outros veículos de interação. A proxêmica refere-se ao uso do espaço na comunicação, o uso humano do espaço como uma elaboração especializada da cultura. $\mathrm{O}$ homem estrutura inconscientemente o microespaço. A maioria dos trabalhos dessa área limita-se a discutir o uso do espaço interpessoal, embora a proxêmica tenha uma abordagem mais ampla: condução das transações cotidianas, organização do espaço em casas e edifícios e, em última instância, o layout de cidades. De acordo com essa teoria, existem três tipos básicos de espaço, que são estruturados de várias formas por pessoas de determinada cultura: a) 
espaço de características fixas: disposições estruturais inalteráveis em torno de nós (paredes e salas por exemplo); b) espaço de características semifixas: modos como são dispostos os obstáculos móveis (como peças de mobiliário); c) espaço informal: território pessoal em torno do corpo, que se desloca com a pessoa (determina a distância interpessoal). Na cultura americana, por exemplo, existem quatro distâncias discerníveis: íntima $(0-50 \mathrm{~cm})$; pessoal $(50 \mathrm{~cm}-1,20 \mathrm{~m})$; social $(1,20 \mathrm{~m}-3,50 \mathrm{~m})$; pública (acima 3,50 m). De acordo com Hall, quando pessoas travam uma conversa, existem oito fatores envolvidos, ao mesmo tempo, na distância entre elas. 1. fatores de postura-sexo; 2. eixo sociófugo (desencorajamento); eixo sociópeto (encorajamento); 3. fatores cinésicos; posicionamento das partes do corpo; 4. comportamento de contato - relações táteis (intencionais ou acidentais), duração, intensidade; 5. código visual: modo de contato ocular; 6. código térmico: calor percebido no outro comunicador; 7. código olfativo: grau de odor percebido no momento da conversação; 8. volume da voz: relaciona-se com o espaço interpessoal.

Uma outra teoria aplicável é a Teoria Funcional de Paul Ekman e Wallace Friesen. Esses autores abordam a atividade não-verbal sob três perspectivas: a) origem: fonte de um ato, comportamento não-verbal humano; pode se referir a um comportamento inato (integrado no sistema nervoso), constante da espécie (universal) ou variável entre cultura, grupo, indivíduo; b) codificação: relação entre o ato e o seu significado. A codificação da atividade não-verbal pode ser: b1) arbitrária: menear a cabeça para dizer "sim"; b2) indicial: choro, como codificação intrínseca: é um sinal da emoção, mas é a própria emoção; b3) icônico: movimento ilustrativo da mão; c) uso: o ato não-verbal é variável pelas circunstâncias; c1) uso comunicativo: deliberadamente para veicular um significado; c2) uso interativo: influencia o comportamento dos participantes; c3) uso informativo: não-intencional, mas fornece uma informação a quem o percebe.

Como se pode observar, esses três conteúdos oferecem um certo suporte para a percepção de dados informacionais para uma leitura gestual, aplicável diretamente ao movimento executado no cotidiano, mas também para uma observação de processos estéticos que concebem posturas corporais e gestuais quer de uma foto ou pintura que recuperem a figura humana, quer de um espetáculo teatral ou de dança, quer de um registro fílmico ou videográfico.

Por fim, há que se ressaltar a probidade de uma abordagem gestual do texto literário conforme suas notações gestuais e proxêmicas no discurso narrativo, poético ou dramático. Em Jornada noite adentro: a rein- 
venção da tragédia nas palavras da dança (Souza, 1998), pode-se ler um projeto efetivo de análise textual a partir de notações gestuais e proxêmicas, por exemplo, num excerto do romance $A$ mão e a luva, de Machado de Assis, quando são apontadas detalhadamente as referências proxêmicas, gestuais e posturais de um passeio que a personagem feminina faz no jardim, sob o olhar da personagem masculina, que vai compondo-lhe a imagem a partir dos fragmentos que são oferecidos por entre os arbustos. Além disso, o tema central do capítulo 3, "O discurso do corpo e a dança das palavras", trata de averiguar, em várias traduções do texto de Édipo $r e i$, as notações de gestualidade das personagens, presente no discurso verbal.

\section{A interdisciplinaridade e a intertextualidade}

Pensando-se em termos de relações entre obras artísticas, há que se retomar os conceitos de intertextualidade e de interdisciplinaridade. Nesse sentido, para Leila Perrone-Moysés, em arte não há progresso, não há avanços em termos de valor e, a partir disso, estabelece, em seu texto "Literatura comparada: intertexto e antropofagia" alguns pressupostos: a) a literatura nasce da literatura; cada obra nova é uma continuação por consentimento ou por contestação, das obras anteriores, dos gêneros e de temas já existentes; escrever é, pois, dialogar com a literatura anterior e com a contemporânea; b) ler é atentar para a obra em seus processos dinâmicos de produção e recepção; c) um estudo da intertextualidade tem por objetivo examinar de que modo ocorre a produção do novo texto. Perceber os processos de rapto, absorção e integração de elementos alheios na obra nova; d) a originalidade nunca é mais do que um arranjo novo.

Ainda nesse sentido, o autor Laurent Jenny (1979) considera a essência da intertextualidade o trabalho de assimilação e de transformação que caracteriza todo e qualquer processo intertextual. O processo da intertextualidade se dá operado por um texto centralizador, que detém o comando de sentido. Há que se verificar, de texto para texto, as relações como conjuntos estruturados; perceber, termo a termo, a recuperação, a adaptação, a perversão e contradição. O novo texto passa a ser o lugar de fusão de sistemas de signos originários das pulsões individuais e do social. Quer dentro de uma mesma forma de arte, quer interdisciplinarmente, existe esse processo de centralização de textos materiais numa nova configuração. Ainda para Laurent Jenny, há que perceber a mudança, de um texto 
para o outro, do tom, da ideologia, do movimento, pelas suas contradições e simetrias.

Assim, seja qual for o seu suporte ideológico confesso, o uso intertextual dos discursos corresponde sempre a uma vocação crítica, lúdica e exploradora. Cabe lembrar que Gilberto Pinheiro Passos (1996) chama a intertextualidade de um conceito operatório, explicando que o caminho dos fenômenos intertextuais apresenta certa cadeia de ecos metonímicos dos textos assimilados a se atrair e refletir (no caso em se tratando do romance Memórias póstumas de Brás Cubas de Machado de Assis, mas que aqui se toma como concernente, em verdade, a qualquer processo intertextual.

\section{A tragédia grega no mundo moderno: as releituras de Édipo}

A tragédia, proveniente das festas dionisíacas, veio a ser uma das mais impressionantes revelações da arte da Grécia Antiga e exerceu influência decisiva na formação da mentalidade popular. Atenas foi a cidade onde nasceram três gerações de poetas trágicos: Ésquilo, Sófocles, Eurípedes; os três únicos cujas obras resistiram ao tempo e chegaram até nós, não perdendo sua magnitude no decurso dos séculos. Cabe salientar que a leitura de uma tragédia hoje assume a perda de uma parte da intraduzível beleza que só os helenos daquele tempo podiam apreciar. Trata-se de um inavaliável tesouro, que se torna mais acessível, sem dúvida, aos que conhecem a velha Grécia e as suas criações. Com efeito, só a leitura do texto já pode proporcionar certa dose de impressões, mas na verdade o conhecimento da lenda e da história, das concepções religiosas e políticas dos gregos antigos e das fontes e rumos de sua arte nos habilitam a compreender e apreender toda a beleza da tragédia ateniense. A história do infeliz rei Édipo liga-se aos dois crimes de maior terror nos gregos antigos: o parricídio e o incesto. $\mathrm{O}$ inexorável fatalismo: nenhuma criatura humana pode fugir ao seu destino, é a tônica central. Por sobre a obra literária constrói-se o mito que, da arte à psicologia, vem sendo recontado no decorrer da história da cultura ocidental. O texto e o mito de Édipo Rei atuam como legis-signo para inúmeras atualizações singulares. Cada releitura transforma-se num sin-signo, numa efetivação de uma potencialidade particular. 
No mundo moderno, o que se percebe é o processo de apropriação, citação, intertextualidade, uma recorrência muito grande ao paradigma formado pela tradição cultural (percebendo aqui que o próprio conceito de tradição é, por si só, motivo para vários outros estudos, o que não procede no momento). E, pensando-se na tradição ocidental, o texto de Sófocles em questão configura-se como uma obra capital, o que justifica a sua divulgação e as inúmeras abordagens existentes.

A reinvenção da tragédia, proposta por Martha Graham quanto à coreografia, oferece a oportunidade de verificação de processos efetivos de estruturação de "ecos metonímicos" da tragédia de Édipo numa nova configuração sígnica. Desse modo, analisar a representação em vídeo de Night Journey confere um alto grau de complexidade, pois trata-se de uma obra plural, resultado da fusão de vários textos não-verbais concomitantes: $1^{\circ}$ ) é um espetáculo cênico que sofre a ação da focalização cinematográfica (em 1947, provavelmente, os registros em vídeo ainda eram precários, mas de qualquer forma o pouco que se encontra atualmente de material original das coreografias de Martha Graham está em fitas de vídeo); $2^{\circ}$ ) utiliza música, composta por William Schuman, que possui toda a sua estrutura sígnica, e que, por assim dizer, pode ditar uma estrutura rítmica para as seqüências de movimentos estruturados na coreografia; $3^{\circ}$ ) utiliza cenário e objetos de cena, feitos por Isamu Noguchi especialmente para a peça, mas que trazem em si significações próprias e traçam, por si só, "ecos metonímicos" com relação aos objetos que representam, conforme se discutirá; $4^{\circ}$ ) compõem-se coreograficamente pela técnica de dança moderna, estruturada por Martha Graham; essa técnica constrói praticamente uma nova gramática para o corpo, distinta das formas tradicionais (balé clássico) e outras tendências modernas anteriores a ela, que eram muito generalizadoras e voltadas para elementos da natureza (Isadora Duncan, por exemplo); nessa técnica, o corpo se movimenta representando pulsões internas, principalmente em movimentos que partem do tronco, numa freqüência que coincide com a respiração entremeando a tensão e o relaxamento, sem nunca disfarçar ou camuflar o esforço físico e as relações de peso; $5^{\circ}$ ) possui um eixo dramático-narrativo que se faz intertextual à tragédia de Sófocles; nesse sentido, propõe um espetáculo que tem essência teatral, usando das técnicas corporais para a construção de personagens, que irão interagir em cena sem o recurso verbal, potencializando e iconizando o texto primeiro, no dizer de Gilberto Pinheiro Passos (1996), tratar-se-ia de uma nova operação escritural e ler esse processo seria refazer o caminho da relação criativa; $6^{\circ}$ ) pressupõe uma transposição de linguagem do texto verbal artístico 
(literário-teatral) para o texto nãoverbal artístico (corporal-dança); o processo de empréstimo se dá, portanto, numa transcodificação que não se opera, por outro lado, numa busca incessante de recontar, num outro veículo, a mesma história, mas instaura uma poética do empréstimo, que absorve e recria, reinventa o texto primeiro. Ao mesmo tempo que recupera, exigindo o repertório do espectador, dilacera e subverte, explicitando o jogo de combinações novas, revitalizando a obra da tradição e expondo a modernidade.

De fato, cada um desses tópicos é responsável por instaurar um processo de comunicação não-verbal, analisável pela Semiótica. Nesse sentido, a obra supõe uma leitura atenta, feita por multicanais. Ou seja, é exigida uma visão holística, uma percepção global, da soma de todos esses textos não-verbais para a formulação de uma possibilidade interpretativa. Trata-se, em primeira instância, de um domínio do icônico, uma vez que o que se oferece ao espectador é a gramática dos movimentos corporais: muitas informações imprecisas ao mesmo tempo. No entanto, em menor grau, podem-se perceber índices de vários tipos (ecos metonímicos) que permitem - por exemplo - a relação com a tragédia, a expressão dramática das personagens, o corpo que se precipita ao chão insistentemente, o ritmo musical que cria um clima tenso, composto alternando seqüências em adágio e stacatto.

Por fim, alguns símbolos convencionais (como a corda, os ramos verdes, a cama estilizada) dão contorno específico à peça e, por assim dizer, referencializam-na. Resgatando-se os dizeres de Lucrécia Ferrara, tem-se aqui uma fragmentação de códigos, variedade e combinação de signos que constituem uma linguagem complexa. As emanações que surgem para o interpretante atingem os sentidos simultaneamente, sem uma ordenação convencional. Configura-se assim uma intersemiotização, como possibilidade de abordagem analítica. Como texto não-verbal artístico, a coreografia é de baixa definição informacional, o que contribui para a plurissignificação. Tem no corpo humano a fonte central de expressão, que é responsável por conduzir a intersemioticidade, interligando os elementos cênicos, o espaço, o tempo, a música, e oferecendo a intertextualidade com a referência literária (e ao mesmo tempo com os imensos paradigmas de releituras dos prórpios mitos e obras que foram sendo produzidos na diacronia). O que se recebe como emanação dos sentidos são os movimentos no espaço cênico, que conduzem a interpretação e são responsáveis pela caracterização das personagens que não contam suas emoções, mas vivem-nas corporalmente, fazendo do ator de recepção uma experiência única. Assim, o corpo é a fonte de elaboração 
dos ícones, índices e símbolos para ao mesmo tempo manter o diálogo do novo texto com a tragédia e propor uma reinvenção dela.

É nítido o trabalho de assimilação e transformação do processo intertextual. Nesse sentido, Night Journey é um texto centralizador que encerra em si diversos textos materiais, o que se dá de forma interdisciplinar. O diálogo básico é entre dança e literatura, mas subjazem elementos de outras artes, como a escultura, a cenografia, a música e o teatro. Em resumo, Night Journey é uma nova obra artística com peso e importância do próprio diálogo que estabelece. Para a continuidade do trabalho, propõe-se a análise semiótica do aspecto primordial da obra artística analisada, que é a coreografia.

\section{Relações estruturais da coreografia: componentes sígnicos}

A análise sintática denota o domínio do icônico. Do ponto de vista da materialidade, uma coreografia, nos dizeres de Rudolf Laban (o estudioso do movimento), possui uma corêutica (a plasticidade e delineio do movimento) e uma euquinética (expressividade, intensidade, leveza). Tais elementos podem ser analisados como quali-signos. A dança moderna considera as possibilidades expressivas do corpo como um todo: cabeça, tronco e membros agem conjuntamente em movimentos posturais. A técnica básica, proposta por Martha Graham, é a contração e a expansão, tendo como ponto de partida o centro do corpo: a região do abdômen e da pélvis. Na coreografia em questão, há qualidades específicas de movimento. A utilização dos planos baixo, médio e alto perfazem os níveis em que o movimento pode ocorrer. Percebe-se uma tendência a considerar o chão, o movimento rasteiro e pesado; poucas vezes o corpo está ereto e firme, quase nunca sai do chão para saltos. É constante a oposição entre movimentos circulares e movimentos angulosos no nível corporal. Quanto ao deslocamento pelo espaço, esse também se dá ora por círculos ora por linhas (diagonais, horizontais ou transversais), numa sucessão que lembra quadros em movimento, e cada cena - ao menos percebida dentro da filmagem a que se teve acesso - comporta-se como uma pintura, tal a plasticidade conferida pelo delineio do movimento no espaço.

Por tudo isso, na primeiridade, a coreografia se fundamenta como texto não-verbal, signo de qualidade via fragmentação. Na secundidade, 
vê-se a aceleração do ritmo dos movimentos e a intensidade expressiva que se tornam indiciais. Passa-se assim para o caráter dramático e/ou trágico da coreografia, uma vez que os movimentos, da maneira como vão se encadeando, expressam desespero, amor, ódio, revelação, culpa e arrependimento. Como singular, a composição coreográfica é uma realização única, fazendo a interação dos elementos corporais e espaciais. $\mathrm{O}$ conjunto dos movimentos seqüenciados sugere um objeto imediato, que é o corpo humano, masculino e feminino, que aparece em movimentos modelizados, não realistas. Como legi-signo, a coreografia possui uma configuração icônica associada a uma configuração gestual que a torna modelar. Na teoria de Birdwhistell, estaríamos estudando o nível pré-cinésico, ou seja, a estrutura fisiológica do movimento, como os cines estariam realizando-se e interligando-se. Do ponto de vista de Hall, estariam sendo considerados os três níveis de espaço: o fixo (palco), o semifixo (objetos de cena que delimitam a movimentação) e o informal (íntimo para Édipo/Jocasta; pessoal para Tirésias e o Coro). Além disso, podem ser apontados os fatores diferenciadores de: postura/sexo, comportamento de contato e fatores cinésicos. Na teoria funcional de Ekman e Friesen, a movimentação poderia ser analisada pela origem: o comportamento variável de cultura para cultura.

Ainda estruturalmente, há a intenção narrativa e dramática que permite, no nível da materialidade, a possibilidade do diálogo intertextual, uma estrutura que encadeia movimentos e quadros, de modo análogo à seqüência narrativa e/ou dramática, mas distinta do encadeamento da tragédia original, uma vez que se utiliza de um recurso de flashback psicológico - tendência moderna da narrativa, do teatro e do cinema.

\section{Dramaticidade e a narrativa da coreografia: possibilidades semânticas}

Do ponto de vista semântico, ressalta-se o conteúdo dramático-narrativo de Night Journey, composta para o palco em 1947 e adaptada para o vídeo em 1961. Em Memória do sangue (Uma autobiografia), a própria Martha Graham (1991, p.143-4) explica:

é uma dança entre Jocasta e Édipo, mãe e filho. É uma dança intensamente erótica ... Para Jocasta, eu vi além do momento em que a descobrimos no

palco ... Jocasta está parada aos pés da cama com cordas de seda nas mãos 
erguidas para o alto. Antes desse momento eu a senti atravessando os corredores com colunas numa fúria frenética para chegar às grandes portas ... Jocasta abre as portas para essa alcova de sua vida e as fecha atrás de si ... O grande pecado do incesto dominará sua vida posterior. Inadvertidamente, ela conhecera o rapaz que, com o passar do tempo, aceita como seu amante, marido e pai de seus filhos. Só muito depois ela percebeu que cometera o crime do incesto, ao se casar com o próprio filho. Sua vida de amor e maternidade se passou nesse aposento sagrado. Eu gostaria de acreditar que ela nasceu nesse aposento ... Sua vida de amor se consumou ali. O nascimento de seus filhos ocorreu ali. E ela se precipitou para lá a fim de encontrar o destino final de sua vida, o suicídio. Levava nas mãos o cordão umbilical que era para ela, enfim, o símbolo de seu crime contra a civilização e a vida. Mas, quando ela está para passar a corda sobre a cabeça a fim de se estrangular, Tirésias faz soar seu bastão de madeira sobre o chão despertando-a para a consciência dessa exigência, de que ela reviva o passado na totalidade, antes que lhe sejam permitidos a paz e o esquecimento da morte.

Sendo assim, Night Journey é a leitura singular que Martha Graham faz da lenda de Édipo. No processo de reinvenção, o mito é recontado do ponto de vista da personagem Jocasta, o que denota uma inversão ao mesmo tempo estrutural e semântica, que instaura todo um processo de releitura. Ressaltam-se, desse modo, componentes semânticos não observáveis na peça original: o ponto de vista feminino, da mãe, da esposa e da amante, não só é levado em conta como temas, mas aparece representado dialeticamente. Ao assumir o eixo dramático centrado nessa personagem feminina, cria-se um pólo gerativo de sentidos, uma transgressão ao modelo, no processo da intertextualidade.

O conteúdo das modernas produções de espetáculo, interdisciplinares e multicanais, envolve a realização da obra de arte e contribui para a plurissignificação em torno do tema. No nível do movimento, os aspectos semânticos, ao serem averiguados pela semiótica, importam como veículos de informação. Vale muito mais a forma como o significado foi passado do que o próprio sentido. Assim, a coreografia fornece mais informação estética do que semântica, porque o que se faz evidente é a gramática inegável dos movimentos no espaço, o que tem o poder de comunicar independentemente de repertórios especializados por parte do receptor.

No entanto, algumas inferências enriquecedoras podem ser feitas. Os agrupamentos (conjuntos) de movimento formam unidades comunicativas, ou seja, os cinemas. A contração do abdômen e a conseqüente curvatura do corpo são constantes nessa coreografia, o movimento su- 
gere (numa leitura tradicional) um cinema com sentido de dor e angústia. A contração da pélvis traz uma informação de cunho sensual; as inclinações para frente ou para trás, terminando no chão, dão a imagem de peso e drama. Além disso, para lembrar o psicanalista Reich, em sua teoria das couraças musculares, toda contração no nível corporal corresponderia a um quadro neurótico e, de qualquer forma, é essa a impressão que se pode obter da cena. Assim, ficam evidentes as possibilidades semânticas no nível da movimentação (cinésico para Birdwhistell e plano da codificação para Hall).

\section{A coreografia como símbolo do enfrentamento do destino}

A produção em vídeo da coreografia traz um texto de apresentação que contextualiza o espectador no sentido do jogo intersemiótico: a interdisciplinaridade literatura/dança, a intertextualidade rei Édipo/Night Journey, bem como a referência ao cenário e à música. O espectador inicia contato com a obra a partir de uma simbologia especificada (que dirige, de certo modo, a interpretação semântica): cenário = aposentos de Jocasta; corda $=$ instrumento para enforcar-se; mas também união a Édipo (cordão umbilical); ramo = fertilidade; coro = sofrimento; cajado $($ cego $)=$ lei $/$ destino; cama $($ dupla $/$ casal $)=$ união matrimonial; figurinos $=$ realeza.

Todos esses elementos interagem com a coreografia que se transforma em narrativa qualitativa, não remetendo às idéias concretas, mas sim às imagens abstratas, dramas psicológicos e existenciais. Propõe uma reflexão sobre o homem e sua impotência sobre o destino (que já havia em Édipo rei) e associa essa impotência à condição feminina. Tudo isso eleva-se ao estatuto trágico, que torna Night Journey, essa jornada noite adentro, um símbolo do grito da mulher em sua posição de geratriz: é o útero que revive pelo movimento a dor da perda do feto que o habitava e o desespero pela constatação do crime de incesto (que representa o retorno daquela perda). Tais interpretações, cabe salientar, são buscas de sentido às metáforas do texto, cuja compreensão não é de todo acessível.

\section{Homologias: para ler a dança}


A coreografia Night Journey apresenta-se como texto não-verbal que, de maneira efêmera, é submetida à ação interpretante do receptor. É também uma linguagem-objeto (sin-signo) e sua leitura poderá ser tida como metalinguagem. Os dados informacionais mostram baixa definição com relação às representações referenciais, sendo constituída por ícones e índices e, em menor grau, por símbolos (convenções). As inferências do interpretante se dão por um processo de associações. Nesse sentido, o receptor, num processo dinâmico, é levado a buscar a contigüidade por metonímias e por dados referenciais.

No entanto, a dança apresenta o signo elaborado artisticamente e, como tal, tem sua significação plurívoca, densa, de difícil penetração. O leitor da dança recorre, então, à similaridade. Como produção compósita, sincrética e sintética ao mesmo tempo, um espetáculo de dança constitui um código intersemiótico, exigindo maior problematização e processos complexos de análise, interpretação e leitura. Além disso, nas relações de similaridade, o esforço intelectual busca referências metafóricas para construção de interpretações virtuais. Esses processos todos, ao que parece, são pertinentes para uma análise de Night Journey, que se comporta na história da dança como processos de composição que possuem correlações explícitas, por exemplo com o trabalho de Picasso (amigo pessoal da coreógrafa) - do que vale notar certo tom cubista na seqüência de movimentos -, principalmente do coro de Night Journey. Em linhas gerais, apesar de certo ranço expressionista, podem-se verificar homologias estruturais entre essa composição coreográfica a alguns artistas, de várias áreas, como nos processos da poética verbal (João Cabral de Melo Neto), da narrativa psicológica e sincrética (Clarice Lispector/Guimarães Rosa), da pintura moderna (Mondrian e, mesmo, Paul Klee ). Cabe ressaltar que esse exercício de leitura vem apenas introduzir algumas questões acerca de uma leitura efetiva dos processos intersemióticos envolvidos em Night Journey, uma vez que o contato com as teorias sobre o comparatismo entre artes está apenas se iniciando.

SOUZA, A. M. Body word. Language confluence in Night Journey. Trans/Form/Ação (São Paulo), v.24, p.163-181, 2001.

- ABSTRACT: The text consists in an exercise of interpretation of Martha Graham's choreography Night Journey (1947) as a recreation of Sophocles'Oedipus Rex (4th Century B.C.). The aim is to sketch a study in which the inter-artistic processes between literature and dance are brought to light. 
- KEYWORDS: Literature; dance; body; language; semiotics.

\section{Referências bibliográficas}

CAMPOS, H. Por uma poética sincrônica. In: . A arte no horizonte do provável. São Paulo: Perspectiva, 1969.

CLÜVER, C. Estudos interartes: Orientação critica. In: ___ . Floresta encantada: os estudos comparatistas hoje. Trad. Yun Jung. Lisboa: Colibri, 2001.

FERRARA, L. D. Leitura sem palavras. São Paulo: Ática, 1986.

GONÇALVES, A. Transição e permanência: Miró e João Cabral: da tela ao texto. São Paulo: Iluminuras, 1989.

GONZALEZ, J. P. Análise da pintura Guernica. Campinas, 1996. (Texto abordado no curso Estética e Semiótica em Artes - Unicamp, 1996.)

GRAHAM, M. Night Journey: coreografia. Direção de Alexander Hammid. New York: 1961. 1 fita de vídeo.

. Memória do sangue (Uma autobiografia). São Paulo: Siciliano, 1993.

JENNY, L. A estratégia da forma. In: Intertextualidade. Coimbra: Livraria Almedina, 1979.

LITTLEJOHN, S. W. Fundamentos teóricos da comunicação humana. Rio de Janeiro: Zahar, 1982.

PASSOS, G. P. Um conceito operatório: a intertextualidade. In: ___ . A poética do legado: presença francesa em Memórias póstumas de Brás Cubas. São Paulo: Annablume, 1996.

PEIRCE, C. S. Semiótica. Trad. José Teixeira Coelho Neto. São Paulo: Perspectiva, 1977.

PERRONE-MOISÉS, L. Literatura comparada: intertexto e antropofagia. In: . As flores da escrivaninha. São Paulo: Companhia das Letras, 1990.

SANTAELLA, L. O que é semiótica. São Paulo: Brasiliense, 1983.

SÓFOCLES. Rei Édipo. Trad. J. B. Mello e Souza. Rio de Janeiro: Ediouro, 1992.

SOUZA, A. M. de. Jornada noite adentro: a reinvenção da tragédia nas palavras da dança. Assis, 1988. Dissertação (Mestrado) - Faculdade de Ciências e Letras, Universidade Estadual Paulista. 